\title{
Gamma-Glutamyl Hydrolase
}

National Cancer Institute

\section{Source}

National Cancer Institute. Gamma-Glutamyl Hydrolase. NCI Thesaurus. Code C103945.

Gamma-glutamyl hydrolase (318 aa, $\sim 36 \mathrm{kDa}$ ) is encoded by the human GGH gene. This protein is involved in the hydrolysis of gamma-linked glutamate bonds. 